\title{
AN ERROR ANALYSIS OF SIMPLE PAST TENSE IN WRITING NARRATIVE TEXT AT SECOND GRADE SMAN 1 CIOMAS
}

\author{
Chotibul Umam \\ Dede Rohadi Fajri \\ Banten Jaya University \\ Serang, Indonesia \\ Chumam.umam@gmail.com
}

\begin{abstract}
The objectives of this study were to identify whether the students make errors and to find the types of errors made by the second grade of SMAN 1 Ciomas in Simple Past Tense in their Narrative Text. The classification of the types of the error of the study was based on Dulay, and the procedure of error analysis used Ellis' procedure. In this study, the writer used content analysis method to describe students' error and analyze the data. The data which were taken from the test focus on Simple Past Tense. The sample of this study was the students of second grade of SMAN 1 Ciomas, in academic year 2015/2016, the class XI IPA consisting of 33 students. Procedure of this study was 68 errors and identifying, describing, recapitulating. The result of this study made errors in misformation (30 or $44.11 \%$ ), addition (14 or 20.58\%), misordering (13 or 19.11\%), and omission(11 or $16.17 \%)$. Based on the study, the writer concludes that the second grade students of SMAN 1 Ciomas, most of students made errors in using Simple Past Tense, and the classification type of error was in misformation.
\end{abstract}

Key words: error analysis, narrative text, simple past tense.

\section{INTRODUCTION}

Writing skill is one of the productive skills that should be mastered in using a language. It is because writing skill has significances role in improving a communicative competence of learning the language.

In learning English, there are four language skills that should be learned. They are listening, speaking, reading and writing. One of the language skills by which someone can express his or her ideas in written form. This skill should be taught to the students in SMAN 1 Ciomas. It is stated in KTSP curriculum of SMA that the students are expected to be able to communicate in English either written or spoken form. It means that these skills should be interrelated and supported one another.

But in fact, most of students of SMAN 1 Ciomas still have difficulties in writing a good text in English. The students' score in writing are still low. Only some students get good score. The problem may be caused by some aspects; the first it rare oportunity to use English because the status of English as a foreign language, not as main daily communication. The second is that the students do not have enough practice in writing text, determining the main idea, using the appropriate word, and arranging 
the sentences. Therefore, the students need to master the structure of the English language, should have enough vocabulary, also know the spelling of the words in order to be able to write correct sentences and arrange them into a good paragraph. Third, the technique used by teacher do not support the students' motivation to write the paragraph. Based on the explanation above, the writer is interested in conducting a research entitled "An Error Analysis of Simple Past Tense in Writing Narrative Text at Second Grade of SMAN 1 Ciomas."

\section{METHOD}

The method of this research was content analysis. It is used to describe the students' errors. First, the writer gave the Narrative writing test to the students in the classroom. Second, the writer collected the students' test then analyzed them by describing the percentage of students' errors in the form and in the usage of simple past tense. The last, the writer interpreted the data about what are the most errors that the students made.

It is essential to focus the problem in order to avoid misunderstanding in interpreting the problem. The writer only focuses on the errors of the students in using Simple Past Tense in writing narrative.

To collect the data, the writer used English writing test. The writer gave the test to know the errors' frequency in using Simple Past Tense in Narrative text. The test is Narrative paragraph writing test.

In this part, to analyze students' answer in forming simple past tense, the writer identified the error items as follows:

1. The writer focuses on students' error in using simple past tense in the narrative texts that students made in the test given.

2. The writer collected and classified the errors based on their types. Then the writer verified the frequency of the errors the students made.

3. The writer then used descriptive analysis technique (presentage) to analyze the data. The formula used Anas Sudijono $(2005 ; 43)$ is as follow:

$$
P=\frac{F}{N} x 100 \%
$$

$\mathrm{P}=$ percentage

$\mathrm{F}=$ frequency of error made

$\mathrm{N}=$ number of sample which observed

The validity of the test means to determine if they measure what is intended to measure. In this research, the writer prepared the test that is not difficult and 
not too easy. The writer set the test that relates to the curriculum that the teacher uses to teach English grammar that has been given to the students when they were in 2015/2016 second year students. The materials for the test were taken and developed from the handbook of eleventh grade students of SMA, not only that the test also approved by the advisors. Based on the explanation about the test, the writer considered that the test is valid.

\section{DISCUSSION}

After collecting the data from the test, the writer found some errors made by the students in using Simple Past Tense in writing narrative text.

\begin{tabular}{|c|c|c|c|}
\hline $\begin{array}{l}\text { Citizen } \\
\text { directlyatta } \\
\text { ck and kill } \\
\text { the Beast }\end{array}$ & $\begin{array}{l}\text { Misformati } \\
\text { on } \\
\text { Misorderin } \\
\mathrm{g}\end{array}$ & $\begin{array}{l}\text { Misformati } \\
\text { on } \\
\text { 'attack' and } \\
\text { 'kill' should } \\
\text { be replaced } \\
\text { by } \\
\text { 'attacked' } \\
\text { and 'killed' } \\
\text { Misorderin } \\
\text { g } \\
\text { 'citizen } \\
\text { directly } \\
\text { attack and } \\
\text { kill the } \\
\text { Beast' } \\
\text { should be } \\
\text { replaced to } \\
\text { 'citizen } \\
\text { attacked and } \\
\text { killed the } \\
\text { Beast } \\
\text { directly' }\end{array}$ & $\begin{array}{l}\text { Citizen } \\
\text { attacke } \\
d \text { and } \\
\text { killed } \\
\text { the } \\
\text { Beast } \\
\text { directl } \\
y\end{array}$ \\
\hline
\end{tabular}

Table 4.6

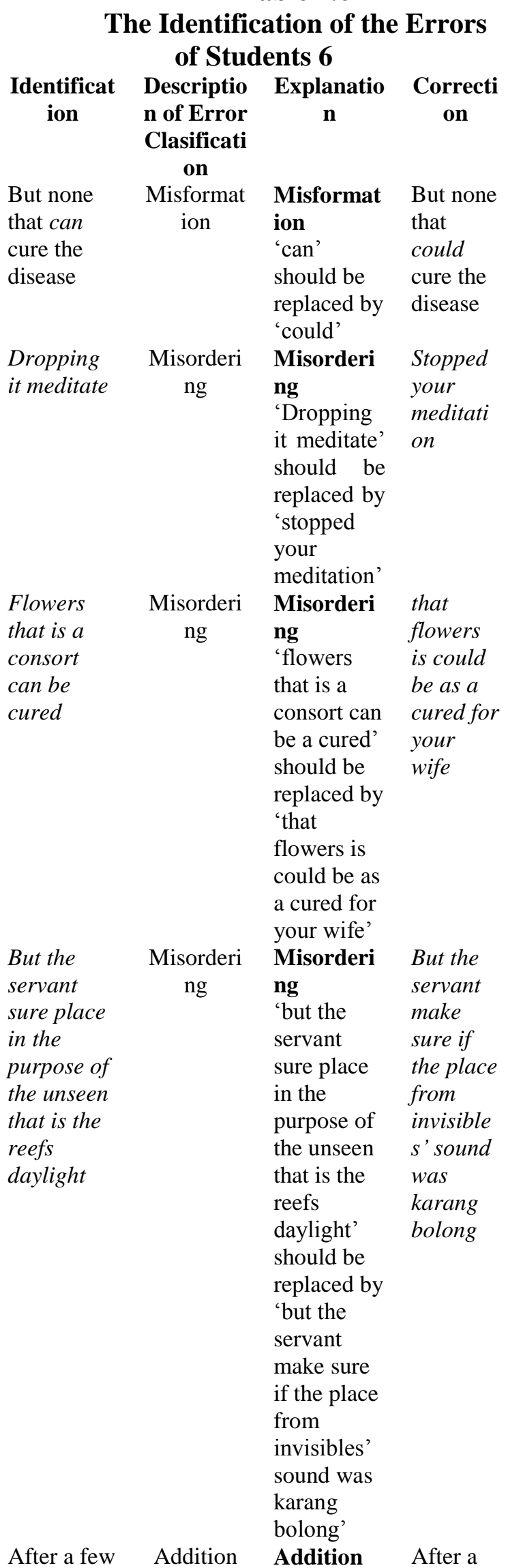


Volume 1 No. 1, Agustus 2018

Universitas Banten Jaya

$\begin{array}{ll}\text { days walk } & \text { 'walk' few days } \\ \text { should be } \\ \text { deleted }\end{array}$

Table 4.7

The Identification of the Errors of Students 7

Identificat
ion

$\begin{array}{ccc}\text { Descriptio } & \text { Explanatio } & \text { Correcti } \\ \text { n of Error } & \mathbf{n} & \text { on }\end{array}$

Tinker Bell Misformat

tells about

ion

life

Named
Tinker Bell
lives in the
laughter

That is

inuse by

the fairies

Misformat
ion
Addition
Misorderi
ng

Misformat
ion
'tells'
should be
replaced by
'told'

Tinker

Bell told

about

life

ion

Tinker

'lives'

should be

replaced by

'lived'

Addition

'named'

should be

deleted

Misorderi

ng

'have of

making and

repairing

equipment'

should be

replaced by

'have to

make and

repair the

equipment'

Misformat Misformat

ion

'is' and

'use'

should be

replaced by

'was' and

'used'

Addition

'in' should

be deleted

However

Misformat

Misformat

Tinker Bell

who do not

have the

natural

talent ion

ion

'do not'

should be

replaced by

'did not'
Bell

lived in

the

laughter

have to
make
and
repair
the
equipme
nt

wa

used by

the

fairies

Merchant

can not be

woken

from his

bed

Was

greeting

the rich

merchant

bodyguard

However

Tinker

Bell who

did not

have the

natural

talent

lecturer

was not to

beggars
Table 4.8

The Identification of the Errors of Students 8

$\begin{array}{cccc}\text { ion } & \begin{array}{c}\text { Descriptio } \\ \text { n of Error } \\ \text { Clasificati } \\ \text { on }\end{array} & \text { Explanatio } & \begin{array}{c}\text { Correcti } \\ \text { on }\end{array} \\ & & & \\ & & \end{array}$

Addition

Misformat ion

Addition

A rich

'that'

should be

merchant

does not

Omission

deleted

help but

Misformat

ion

threw

'throw'

should be

replaced by

'threw'

Omission

'him' and

'out'

should be

replaced

after

'threw'

Misorderi

Misorderi

and

ng

'and the

lecturer

talked to

was not to

don't be

become

beggars'

should be

replaced by

'and talked

to him to

don't be a

beggar'

Misformat
ion

Misformat

ion

'can not be

woken'

should be

replaced by

'couldn't

wake up'

Addition

Addition

'was'

should be

deleted

merchant

Misformat

ion

'greeting'

should be

replaced by

'said'
Said the

rich

bodygua

Merchan

couldn't

wake up

from his

bed

rd 
Table 4.9

\begin{tabular}{|c|c|c|c|}
\hline \multicolumn{4}{|c|}{$\begin{array}{l}\text { The Identification of the Errors } \\
\text { of Students } 9\end{array}$} \\
\hline $\begin{array}{l}\text { Identificat } \\
\quad \text { ion }\end{array}$ & $\begin{array}{c}\text { Descriptio } \\
\text { n of Error } \\
\text { Clasificati } \\
\text { on }\end{array}$ & $\begin{array}{c}\text { Explanatio } \\
\mathbf{n}\end{array}$ & $\begin{array}{l}\text { Correcti } \\
\text { on }\end{array}$ \\
\hline $\begin{array}{l}\text { One day } \\
\text { there lived } \\
\text { a } \\
\text { grandfathe } \\
\text { rold }\end{array}$ & $\begin{array}{l}\text { Misorderi } \\
\text { ng }\end{array}$ & $\begin{array}{l}\text { Misorderi } \\
\text { ng } \\
\text { 'grandfathe } \\
\text { r old' } \\
\text { should be } \\
\text { replaced by } \\
\text { 'old man' }\end{array}$ & $\begin{array}{l}\text { One day } \\
\text { there } \\
\text { lived an } \\
\text { old man }\end{array}$ \\
\hline $\begin{array}{l}\text { He did not } \\
\text { have a } \\
\text { child while } \\
\text { his wife } \\
\text { was dead }\end{array}$ & $\begin{array}{l}\text { Misformat } \\
\text { ion }\end{array}$ & $\begin{array}{l}\text { Misformat } \\
\text { ion } \\
\text { 'while' } \\
\text { should be } \\
\text { replaced by } \\
\text { 'and' }\end{array}$ & $\begin{array}{l}\text { He did } \\
\text { not have } \\
\text { a child } \\
\text { and his } \\
\text { wife was } \\
\text { dead }\end{array}$ \\
\hline $\begin{array}{l}\text { He likes to } \\
\text { all fishing } \\
\wedge\end{array}$ & $\begin{array}{l}\text { Misformat } \\
\text { ion } \\
\text { Addition } \\
\text { Omission }\end{array}$ & $\begin{array}{l}\text { Misformat } \\
\text { ion } \\
\text { 'likes' } \\
\text { should be } \\
\text { replaced by } \\
\text { 'liked' } \\
\text { Addition } \\
\text { 'to all' } \\
\text { should be } \\
\text { deleted } \\
\text { Omission } \\
\text { 'very } \\
\text { much' } \\
\text { should be } \\
\text { replaced } \\
\text { after } \\
\text { 'fishing' }\end{array}$ & $\begin{array}{l}\text { He liked } \\
\text { fishing } \\
\text { very } \\
\text { much }\end{array}$ \\
\hline $\begin{array}{l}\text { The old } \\
\text { man that } \\
\text { went to a } \\
\text { lake }\end{array}$ & Addition & $\begin{array}{l}\text { Addition } \\
\text { 'that' } \\
\text { should be } \\
\text { deleted }\end{array}$ & $\begin{array}{l}\text { The old } \\
\text { man } \\
\text { went to a } \\
\text { lake }\end{array}$ \\
\hline $\begin{array}{l}\text { The old } \\
\text { man hears } \\
\text { a sound }\end{array}$ & $\begin{array}{l}\text { Misformat } \\
\text { ion }\end{array}$ & $\begin{array}{l}\text { Misformat } \\
\text { ion } \\
\text { 'hears' } \\
\text { should be } \\
\text { replaced by } \\
\text { 'heard' }\end{array}$ & $\begin{array}{l}\text { The old } \\
\text { man } \\
\text { heard a } \\
\text { sound }\end{array}$ \\
\hline
\end{tabular}

Table 4.10

\begin{tabular}{|c|c|c|c|}
\hline $\begin{array}{l}\text { Identificat } \\
\text { ion }\end{array}$ & $\begin{array}{c}\text { Descriptio } \\
\text { n of Error } \\
\text { Clasificati } \\
\text { on }\end{array}$ & $\begin{array}{c}\text { Explanatio } \\
\mathbf{n}\end{array}$ & $\begin{array}{l}\text { Correcti } \\
\text { on }\end{array}$ \\
\hline $\begin{array}{l}\text { He lives } \\
\text { alone } \\
\text { lonely }\end{array}$ & $\begin{array}{l}\text { Misformat } \\
\text { ion } \\
\text { Addition }\end{array}$ & $\begin{array}{l}\text { Misformat } \\
\text { ion } \\
\text { 'lives' } \\
\text { should be } \\
\text { replaced by } \\
\text { 'lived' } \\
\text { Addition } \\
\text { 'lonely' } \\
\text { should be } \\
\text { deleted }\end{array}$ & $\begin{array}{l}\text { He lived } \\
\text { alone }\end{array}$ \\
\hline $\begin{array}{l}\text { With did } \\
\text { not know } \\
\text { tired }\end{array}$ & Addition & $\begin{array}{l}\text { Addition } \\
\text { 'know' } \\
\text { should be } \\
\text { deleted }\end{array}$ & $\begin{array}{l}\text { With did } \\
\text { not tired }\end{array}$ \\
\hline $\begin{array}{l}\text { Because to } \\
\text { meet the } \\
\text { needs }\end{array}$ & $\begin{array}{l}\text { Misformat } \\
\text { ion }\end{array}$ & $\begin{array}{l}\text { Misformat } \\
\text { ion } \\
\text { 'meet' } \\
\text { should be } \\
\text { replaced by } \\
\text { 'fulfill' }\end{array}$ & $\begin{array}{l}\text { Because } \\
\text { to } \\
\text { fulfillthe } \\
\text { needs }\end{array}$ \\
\hline $\begin{array}{l}\text { The needs } \\
\text { of the life } \\
\text { of the day } \\
\text { of the day }\end{array}$ & $\begin{array}{l}\text { Misorderi } \\
\text { ng }\end{array}$ & $\begin{array}{l}\text { Misorderi } \\
\text { ng } \\
\text { 'the needs } \\
\text { of the life } \\
\text { of the day } \\
\text { of the day' } \\
\text { should be } \\
\text { replaced by } \\
\text { 'the needs } \\
\text { of life day } \\
\text { by day' }\end{array}$ & $\begin{array}{l}\text { The } \\
\text { needs of } \\
\text { life day } \\
\text { by day }\end{array}$ \\
\hline
\end{tabular}

Table 4.11

The Recapitulation of Students' Errors

$\begin{array}{ccccc}\begin{array}{c}\text { Stude } \\ \text { nts }\end{array} & \begin{array}{c}\text { Omiss } \\ \text { ion } \\ \text { Tyde }\end{array} & \begin{array}{c}\text { Additi } \\ \text { on }\end{array} & \begin{array}{c}\text { Misorde } \\ \text { ring }\end{array} & \begin{array}{c}\text { Misforma } \\ \text { tion }\end{array} \\ \begin{array}{c}\text { Stude } \\ \text { nt 1 }\end{array} & 3 & 2 & 1 & 3 \\ \begin{array}{c}\text { Stude } \\ \text { nt 2 }\end{array} & 1 & 1 & 1 & 3 \\ \begin{array}{c}\text { Stude } \\ \text { nt 3 }\end{array} & 2 & - & - & 3 \\ \begin{array}{c}\text { Stude } \\ \text { nt 4 }\end{array} & 2 & 1 & 1 & 4 \\ \begin{array}{c}\text { Stude } \\ \text { nt 5 }\end{array} & 1 & 1 & 3 & 4 \\ \begin{array}{c}\text { Stude } \\ \text { nt 6 }\end{array} & - & 1 & 3 & 1 \\ \begin{array}{c}\text { Stude } \\ \text { nt 7 }\end{array} & - & 2 & 1 & 4\end{array}$




$\begin{array}{ccccc}\begin{array}{c}\text { Stude } \\ \text { nt 8 }\end{array} & 1 & 2 & 1 & 3 \\ \begin{array}{c}\text { Stude } \\ \text { nt 9 }\end{array} & 1 & 2 & 1 & 3 \\ \begin{array}{c}\text { Stude } \\ \text { nt 10 }\end{array} & - & 2 & 1 & 2 \\ \text { Total } & 11 & 14 & 13 & 30 \\ & & & 68 & \end{array}$

Table 4.12

\section{Frequency of Students' Error}

$\begin{array}{cccc}\text { No. } & \begin{array}{c}\text { Types of } \\ \text { Error }\end{array} & \begin{array}{c}\text { Frequency } \\ \text { of errors }\end{array} & \text { Precentage } \\ 1 & \text { Misformation } & \mathbf{3 0} & \mathbf{4 4 . 1 1 \%} \\ \mathbf{2} & \text { Addition } & 14 & \mathbf{2 0 . 5 8 \%} \\ 3 & \text { Misordering } & 13 & 19.11 \% \\ 4 & \text { Omission } & 11 & 16.17 \%\end{array}$

Based on the table of students' errors, in can be stated that:

1. Total Errors of Misformation are 30 errors on precentage $44.11 \%$

2. Total Errors of Addition are 14 errors on precentage $20.58 \%$

3. Total Errors of Misordering are 13 errors on precentage $19.11 \%$

4. Total Errors of Omission are 11 errors on precentage $16.17 \%$



\section{Discussion}

Based on the data analysis, that some students of SMAN 1 Ciomas still have not understood well the rule and the usage espacially in forming and changing the verb based on the subject verb agreement in the sentences. That is related to the aspect causes of errors are mother tongue interference for example * grandfather old instead of *old man and overgeneralization for example *He lives alone instead of *He lived alone.

Based on the data analysis, the writer found that the students' commited errors in misformation (30 or $44.11 \%$ ), addition (14 or 20.58\%), misordering (13 or $19.11 \%$ ), and omission (11 or $16.17 \%$ ). From those frequencies, the writer saw that most of students were still confused in using simple past tense, so it needs more pay attention from the English teachers.

Misformation errors are characterized by the use of the wrong form of the morpheme or structure. In other words, the error of using one grammatical form in the place of another grammatical form or the learner supplies something, although it is incorrect. In fact, the classification types of error was often made by the students in learning English, because he explained that this error type show how the surface structure changes and it is possible for the language learners to omit and distort sentence item, so the learners create or maybe they add unnecessary sentence item in the sentence. Generally this type of error can be classified as misformation error. 
From the explanation above, the writer conclude that the Indonesian students were still lack of understanding the English grammar, especially simple past tense because English grammar and Indonesian grammar are quite different.

\section{REFERENCES}

Anas Sudijono. (2005). Pengantar Statistik Pendidikan. Jakarta, PT. Raja Grafindo Persada.

Brown, H. Douglas. (2008). Teaching by Principles: An Interactive Approach to Language Pedagogy

Corder S. P. (1981). Error Analysis and Interlanguage. Oxford University Press.

David Nunan (2001). Teaching English to Speakers of Other Language. Cambridge University Press.

Elaine Walker. (2000). Grammar Practice for Upper Intermediate Students. Longman.

Harmer, J. (2004). How to Teach Writing. Malaysia. Pearson Limited.

Hyland, Ken. (2009). Genre and Second Language Writting. US: The University of Michigan Press

Heidi C. Dulay. (1982). Language Two. New

Irmawati (2011). Error Analysis on Tenses Learnt by The Second Grade Students. UIN, Jakarta.

Nation, I.S.P (2009). Teaching ESL/EFL Reading and Writing. Victoria University in Wellington, New Zealand.

Jeffrey G. Coghill and Stacy Magedanz. (2000). English Grammar: The Learn-by-doing Way to Master English Grammar. Cliffs Notes.

Knapp, P. and Watskin, M. (2005). Genre, Text, Grammar. Australia: University of New South Wales Press Ltd.
Kathleen B. H. (2000). Tense and Aspect in Second Language Aquisition. Oxford - Blackwell.

M. F. Patel and P. M. Jain. (2008). English Language Teaching (method, tools and technique).

Rinda Rizaldi Syarif. (2014). An Error Analysis on Students' Simple Past Tense Mastery in Their Narrative Text. UIN, Jakarta

R. V. Teschner and Eston, E. Evans. (2007). Analyzing the Grammar of English 3rd Edition.

Reid 1993 in Bootchuy (2008). Error Analysis and Interlanguage. Oxford University Press

Rod Ellis. (2005). Analysing Learner Language. Oxford University Press.

R. R. Jordan (2003). Academic Writing Course. Pearson Education Limited.

Wondereference.

(2010). http://www.wordreference.com/defin ition/writing 
Volume 1 No. 1, Agustus 2018

E-ISSN 2622-9056

Universitas Banten Jaya 